\title{
Fermentative Production of Microbial Enzymes and their Applications: Present status and future prospects
}

\author{
Viswanath Vittaladevaram* \\ Vydehi Institute of Biotech Sciences, Bangalore University, Bangalore, Karnataka, India.
}

\begin{tabular}{|c|c|}
\hline ARTICLE INFO & ABSTRACT \\
\hline $\begin{array}{l}\text { Article history: } \\
\text { Received on: } 11 / 05 / 2017 \\
\text { Accepted on: } 05 / 07 / 2017 \\
\text { Available online: } 14 / 08 / 2017\end{array}$ & $\begin{array}{l}\text { Microbial enzymes are widely used in different industries mainly because of vast availability of sources. } \\
\text { Microbial enzymes could be genetically modified and are considered as economical in comparison to plant and } \\
\text { animal enzymes. Production of microbial enzymes by application of fermentation procedures involves microbial } \\
\text { propagation to get desired product. The process of fermentation is classified based on specific parameters. }\end{array}$ \\
\hline $\begin{array}{l}\text { Key words: } \\
\text { Enzyme activity, Enzyme } \\
\text { recovery, Membrane filtration } \\
\text { technique, Microbial sources, } \\
\text { Strain improvement. }\end{array}$ & $\begin{array}{l}\text { Microbial enzymes exhibit wide variety of applications in different industries like food, wine, dairy, baking, } \\
\text { milling, beverages, and cereals. There are different techniques employed to produce microbial enzymes using } \\
\text { downstream processing methods that are aimed at enzyme purification and recovery. The improvement in } \\
\text { concentration, purity and percentage of recovery of enzymes can be achieved based on standard principles which } \\
\text { are microbial sources, improvement of strain and application of membrane augmented downstream processing } \\
\text { method to improve specific activity of enzyme. The article reviews on principles include microbial sources, } \\
\text { methods of strain improvement and modern techniques associated with improvement of enzyme activity and } \\
\text { recovery process. The application of microbial enzymes in various industries and their importance in } \\
\text { biotechnology is highlighted. }\end{array}$ \\
\hline
\end{tabular}

\section{INTRODUCTION}

The process of enzyme production by cultivation of microorganisms involves use of starch substrates in growth media. The reasons for application of microorganisms for production of enzymes in industries are selected after thorough screening process for improvement in enzyme efficiency. Broths subjected to fermentation process are comprised of target protein in higher concentration together with other components present in media, specifically salts and carbohydrates [1-13]. Fermentation method involving downstream processing is useful to carry out extraction, filtration and separation process to remove impurities from the medium $[14,15]$. However there is no method involved in removing specific component from the medium.

During the process of microbial enzyme production, fermentation method involving downstream process augmented

\footnotetext{
* Corresponding Author

Email:viswa.vittal @ gmail.com
}

with membrane is most preferred method to scale-up the process. There is a demand at global level for production of microbial enzymes which are widely used in food, textile and paper industries. Microbial enzymes produced by conventional fermentation methods involving downstream processing reported loss of enzyme activity and also overall recovery of enzyme is found to be very less [16,17]. To improve overall recovery of enzymes and their activity membrane augmented downstream processing method equipped with microfiltration and ultrafiltration membranes is used [18]. This method is aimed to improve the concentration, purity and percentage of recovery of enzymes in fewer steps and overall costs is very low.

Membrane augmented downstream processing has many advantages in comparison to conventional downstream processing. They include -

1) The product quality is good and yield is higher [19].

2) Design of system is flexible and easy to operate the system [20].

3) Considered as Green technology and environment friendly $[21,22]$. 


\section{MICROBIAL SOURCES}

Microbial enzymes produced from industries are selected from different groups of microorganisms and they include bacteria, fungi and yeasts. Many enzymes are produced in industries but most predominant enzymes that are produced on large scale in industries include protease, alpha-amylase, glucose isomerase and glucamylase [23]. Enzymes produced in industries with the help of microorganisms were found to exhibit good biological activity. Microbial source is preferred over plants and animals for production of enzymes mainly because of the following reasons.

1) Enzymes can be produced on large scale and are economical [24, 25].

2) The process of extraction and purification of enzymes from microbial sources is easier in comparison with plant and animal sources [26].

3) Microbial sources are capable of producing variety of enzymes in different environmental conditions in limited space and time period [27].

4) Genetic manipulation is carried out to yield higher quantity of enzymes produced from microbial sources [28].

Some of the industrially produced enzymes produced in large scale using microorganisms as source are mentioned below in Table 1 [29-31].

Table 1: Industrial enzymes and their source of microorganisms.

\begin{tabular}{lll}
\hline Source & Enzyme & Microorganism \\
\hline Bacterial & Proteases & Bacillus Subtilis \\
& Amylases & Bacillus subtilis \\
& Pencillinase & Bacillus subtilis \\
\hline Yeast & Lactase & Saccharomyces fragilis \\
& Invertase & Saccharomyces cerevisiae \\
\hline \multirow{5}{*}{ Fungal } & Proteases & Aspergillus niger \\
& Amylases & Aspergillus oryzae \\
& Pectinases & Aspergillus niger \\
& Catalase & Aspergillus niger \\
& Glucose oxidase & Penicillium notatum \\
& Glucosidases & Aspergillus flavus \\
\hline
\end{tabular}

\section{METHODS OF STRAIN IMPROVEMENT}

Microorganisms are used as source for production of enzymes, biomolecules and proteins in industries. Few examples of source of microorganism include Saccharomyces cerevisiae and Aspergillus niger are widely used in industries for production of enzymes and alcohol. A wild type strain is isolated for process of strain improvement and to increase productivity. To achieve growth rate faster, desirable downstream processing and behavior of fermentor is enhanced by altering cellular genetics and also it is important to understand the fundamentals of physiology and structure of organism.

The strategies differ from each source of microorganism for example in case of fungal source the emphasis is more on porosity of cell wall, differentiation, secretion and branching. Whereas in case of yeast fermentation process involves gene regulation and ploidy through which carbon sources will play a predominant role in production of proteins associated with heterologous gene expression. Wild types of strains which are used for producing metabolic concentrations are not economical. Improvement of strains is considered as cost effective process and it is necessary to produce secondary metabolites [32, 33].

Desirable strain isolation depends on system and they exhibit following features like [34, 35]. Rapid growth, Genetic stability, Non toxic to humans, Large sized cells, Fermentation process time is less and Exhibit tolerance to carbon or nitrogen sources present in higher concentrations.

Few methods that are associated with strain improvement process are Recombinant DNA technology [36], RecombinationProtoplast fusion [37] and Mutations-Site-directed mutagenesis [38]

The successful application of these methods is enhanced by increasing a dose of gene concentration will increase the product activity which includes one or more number of genes, for example enzymes.

\section{IMPROVEMENT OF ENZYME RECOVERY AND ENZYME ACTIVITY}

The membranes are now considered as critical part of enzyme recovery process and it is replacing conventional downstream processing approaches to purify and recovery of enzymes in industries. Membrane filtration technology is considered as most efficient and economical in comparison with traditional approaches. Chemical treatment is replaced by membranes to minimize the costs of analytical, chemical and labor. Membranes are used to achieve optimum yield of enzymes which is very difficult to obtain by application of fermentation derived chemicals such as vitamins, polymers, enzymes and amino acids $[39,40]$.

\subsection{Membrane filtration technology}

Membrane filtration technique augmented downstream processing is employed to remove the impurities to recovery of enzymes. The use of microfiltration, nanoflitration and ultra filtration membranes facilitated in complete removal of impurities and increased the amount of enzyme recovery. The application of membrane filtration technology to purify enzymes is currently used in industries for large scale production of desired enzymes and also to increase the percentage of enzyme recovery and activity [41]. Microfiltration is employed for purification of macromolecules from other molecules like cell debris or proteins. Ultrafiltration and nanofiltration were used during fermentation method involving downstream processing to retain the substrate and enzyme in reactors and remove the reaction inhibiting components [42]. The advantages of using membrane filtration technology over traditional methods include-

1) Membrane filtration technique can be operated at high temperatures [43].

2) Greater efficiency in terms of energy and less time taking process [43]. 
3) Technique is designed according to the specific product requirement [44].

4) Continuous fermentation is preferred over batch fermentation [44].

5) Cost reliable technique [44].

\section{APPLICATIONS OF MICROBIAL ENZYMES}

Enzymes produced in industries are derived from microbial sources and are widely used in industries include leather, foods, textiles, cosmetics, detergents and pharmaceuticals. Applications of microbial enzymes in industries, environment and agriculture are presented below in Figure-1 [45, 46].

Microbial enzymes are widely used in different industries and their applications are mentioned below in Table 2 [47, 48].

\subsection{Importance of Microbial enzymes in Biotechnology}

Microorganisms are majorly used for production of industrial enzymes. Novel developments in biotechnology allowed researchers to conduct safe gene transfer that codes for specific trait from one organism to other. This also helps to improve the production of enzymes and also supply in adequate proportion [48].
Biotechnological tools used in production of microbial enzymes enabled to increase the enzyme quality and production in many ways. The influence of biotechnology in production of microbial enzymes provides many advantages over traditional methods. The genetic modification of a microorganism is targeted to ensure transfer of desired trait by avoiding other undesired traits. Raw materials and energy used for production of enzymes is very less and the products obtained through biotechnological tools will have less impact on environment. Enzymes which are produced through microbial source are used in various industries and are found to be safe and they replace chemical methods which consume energy and pollute environment [49]. The production of microbial enzymes involving biotechnological approaches contributed to overcome the following challenges.

1) Enzyme purity is increased by removal of impurities through reduction process [49].

2) Enzyme efficiency is increased resulting in higher yields [50].

3) Improvement in functioning of desired enzyme proteins [50].

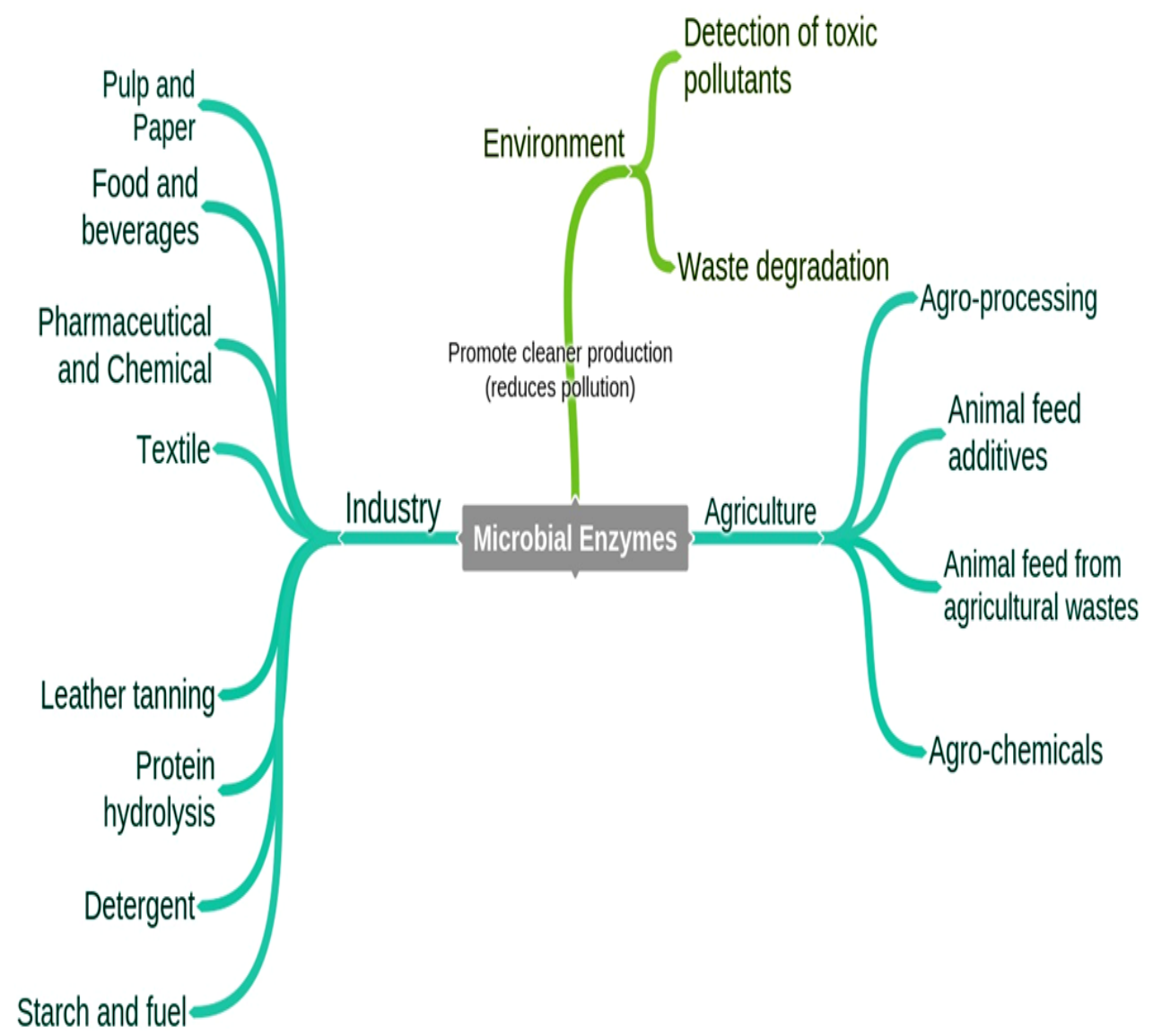

Fig. 1: Applications of Microbial enzymes. 
Table 2: Applications of industrially produced microbial enzymes.

\begin{tabular}{|c|c|c|c|}
\hline Industry & Enzymes & Microbial sources & Applications \\
\hline \multirow{5}{*}{ Pharmaceuticals } & Penicllin oxidase & Pencillium sp. & Antibiotic synthesis \\
\hline & Streptokinase & Streptococci sp. & Anticoagulants \\
\hline & Collagenase & Clostridium perfringens & Skin ulcers \\
\hline & Alpha-amylase & Bacillus sp. & Digestive disorders \\
\hline & Galactosidase & Acinetobacter & Antitumor activity \\
\hline \multirow{4}{*}{ Baking industry } & Amylase & Bacillus sp. & Increase bread shelf life \\
\hline & Lipase & Candida lipolytica & Dough stability \\
\hline & Glucose oxidase & Penicillium purpurogenum & Dough strengthening \\
\hline & Transglutaminase & Streptoverticillium sp. & Enhance flour quality \\
\hline \multirow{2}{*}{ Dairy industry } & Lactase & Lactobacillus sp. & Sweetness to milk \\
\hline & Transglutaminase & Streptoverticillium sp. & Protein polymerization \\
\hline \multirow{2}{*}{ Beverages industry } & Amylase & Bacillus sp. & Starch hydrolysis \\
\hline & Cellulase & Clostridium sp. & Stability and texture \\
\hline \multirow{2}{*}{ Feed industry } & Polygalacturonases & Aspergillus sp.,Bacillus sp. & Animal diet formulation \\
\hline & Xylanase & Bacillus sp. & Digestion of starch \\
\hline \multirow{2}{*}{ Polymer industry } & Lipase & Candida $s p$ & Polyester preparation \\
\hline & Peroxidase & Pseudomonas sp. & Formation of cross-links \\
\hline \multirow{2}{*}{ Paper and Pulp industry } & Xylanase & Bacillus sp. & Augmentation of pulp \\
\hline & Amlyase & Bacillus sp. & Cleanliness of paper \\
\hline \multirow{2}{*}{ Leather industry } & Proteases & Bacillus sp., Aspergillus sp. & Softness, supple, pliable \\
\hline & Lipase & Candida sp. & Degreasing to remove fats \\
\hline \multirow{6}{*}{ Textile industry } & Cutinase & Pseudomonas sp. & Cotton scouring \\
\hline & Collagenase & Clostridium histolyticum & Wool finishing \\
\hline & Pectate lyase & Bacillus sp., & Biosourcing \\
\hline & Amylase & Bacillus licheniformis & Desizing \\
\hline & Laccase & Bacillus subtilis & Fabric dyeing \\
\hline & Catalase & Aspergillus sp. & Bleach termination \\
\hline
\end{tabular}

\section{CONCLUSION}

Microbial enzymes produced in industries are mainly based on three important criteria include microbial sources, strain improvement and methods involved in recovery of enzyme in greater quantities with good quality and efficiency. Membrane filtration technique augmented with downstream processing replaced traditional approaches to increase the percentage of recovery of enzymes and also for improved activity of enzymes. Industries involved in production of microbial enzymes expressed interest in application of membrane filtration technique which showed increase in purity, efficiency and activity of enzymes. The future of modern biotechnology lies in application of genetic engineering procedures for getting desired product by membrane filtration technique augmented with downstream process which is considered as replacement for chemical methods and this process saves energy and keep environment free from pollution.

Financial support and sponsorship: Nil.

Conflict of Interests: There are no conflicts of interest.

\section{REFERENCES}

1. Amro A, Soheir SR. Degradation of castor oil and lipase production by Pseudomonas aeruginosa. Journal of Agricultural \& Environmental Sciences. 2009; 5(4):556-563.

2. Ahlawat S,Dhiman SS, Battan B,Mandhan RP,Sharma J. Pectinase production by Bacillus subtilis and its potential application in biopreparation of cotton and micropoly fabric. Process Biochemistry. 2009; 44(5):521-526.
3. Sabir S, Bhatti HN, Zia MA, Sheikh MA. Enhanced production of glucose oxidase using Penicillium notatum and rice polish. Food Technology and Biotechnology.2007; 45(4):443-446.

4. Sharma R, Chisti Y, Banerjee UC. Production, purification, characterization, and applications of lipases. Biotechnology advances. 2001; 19(8):627-662.

5. Genckal H, Tari, C. Alkaline protease production from alkalophilic Bacillus sp. isolated from natural habitats. Enzym. Microb. Technol. 2006; 39:703-710.

6. Kalishwaralal K, Gopalram S, Vaidyanathan R, Deepak V, Pandian SRK, Gurunathan S. Optimization of $\alpha$-amylase production for the green synthesis of gold nanoparticles. Colloid. Surf. B. Interf. 2010; 77:174-180.

7. Sarrouh B,Santos TM,Miyoshi A,Dia R, Azevedo V. Up-To-Date insight on industrial enzymes applications and global market. Journal of Bioprocessing \& Biotechniques. 2012; S:4-002.

8. Sivaramakrishnan S, Gangadharan D, Nampoothiri KM, Soccol CR, Pandey A. $\alpha$-amylases from microbial sources - An overview on recent developments. Food Technol. Biotechnol. 2006; 44:173-184.

9. Gurumurthy DM, Neelagund SE. Molecular characterization of industrially viable extreme thermostable novel alpha-amylase of geobacillus sp Iso5 Isolated from geothermal spring. J. Pure Appl. Microbiol. 2012; 6:1759-1773.

10. Nigam P, Pandey A. Eds. Biotechnology for Agro-Industrial Residues Utilisation; Publisher Springer Science Business Media B.V. 2009; pp. 1-466.

11. Chirumamilla RR, Muralidhar R, Marchant R, Nigam P. Improving the quality of industrially important enzymes by directed evolution. Mol. Cell. Biochem. 2001; 224:159-168.

12. Chudasama CJ, Jani SA, Jajda HM, Pate HN. Optimization and production of alkaline protease from Bacillus thuringiensis CC7. J. Cell Tissue Res. 2010; 10:2257-2262.

13. Vijayalakshmi S, Venkat Kumar S, Thankamani V. Optimization and cultural characterization of Bacillus RV.B2.90 producing alkalophilic thermophilic protease. Res. J. Biotechnol. 2011; 6:26-32. 
14. Li Y, Niu D, Zhang L, Wang Z, Shi G. Purification, characterization and cloning of a thermotolerant isoamylase produced from Bacillus sp. CICIM 304. J. Ind. Microbiol. Biotechnol. 2013; 40:437-446.

15. Li Q, Yi L, Marek P, Inverson BL. Commercial Proteases: Present and future. FEBS Lett. 2013; 587:1155-1163.

16. Verma N, Thakur S, Bhatt AK. Microbial Lipases: Industrial Applications and Properties. International Research Journal of Biological Sciences. 2012; 1:88-92.

17. Das S, Singh S, Sharma V, Soni ML. Biotechnological applications of industrially important amylase enzyme. International Journal of Pharma and Bio Sciences. 2011; 2(1):486-496.

18. Binod P, Palkhiwala P, Gaikaiwari R. Industrial enzymes: present status and future perspectives for India: present scenario and perspectives. J Sci Ind Res. 2013; 72:271-286.

19. Adrio JL, Demain AL. Microbial enzymes: tools for biotechnological processes. Biomolecules. 2014; 4(1):117-139.

20. Choi JM, Han SS, Kim HS. Industrial applications of enzyme biocatalysis: current status and future aspect. Biotechnol Adv. 2015; 33:1443-1454.

21. Maria Alice ZC,Bernardo DR.White Biotechnology for Sustainable Chemistry. Royal Society of Chemistry: E-Publishing Inc; 2016, pp. 198.

22. Binod P, Piyush P, Raghavendra G, Madhavan KN, Arvind D, Kakali $D$, Ashok P. Industrial enzymes-Present status and future perspectives for India. Journal of Scientific and Industrial Research. 2013;72:271-286.

23. Nigam P. Microbial enzymes with special characteristics for biotechnological applications. Biomolecules.2015; 3(3): 597-611.

24. Seo YB, Park J, Huh IY, Hong SK, Chang YK. Agarose hydrolysis by two-stage enzymatic process and bioethanol production from the hydrolysate. Process Biochem. 2016; 51:759-764.

25. Rodríguez V, Asenjo JA, Andrews BA.Design and implementation of a high yield production system for recombinant expression of peptides. Microb Cell Fact. 2014; 13:1-10.

26. Rajendra S,Manoj K,Anshumali M,Praveen KM. Microbial enzymes: industrial progress in 21st century. Biotech. 2016; 6(2):174.

27. Adrio JL, Demain AL. Microbial Enzymes: Tools for Biotechnological Processes. Biomolecules. 2014; 4: 117-139.

28. Arnold LD, Preeti V. Production of recombinant proteins by microbes and higher organisms. Biotechnology Advances.2009; 27: 297-306.

29. Bueno MM, Thys RCS, Rodrigues RC. Microbial enzymes as substitutes of chemical additives in baking wheat flour-Part II: combined effects of nine enzymes on dough rheology. Food Bioproces. Technol. 2016; 9:1598-1611.

30. Liu Y, Lin S, Zhang X, Liu X, Wang J, Lu F. A novel approach for improving the yield of Bacillus subtilis transglutaminase in heterologous strains. J. Ind. Microbiol. Biotechnol. 2014; 41:12271235.

31. Vengadaramana A. Industrial Important Microbial alpha-Amylase on Starch-Converting Process., Sch. Acad. J. Pharm.2013; 2(3):209-221.

32. Singh R, Kumar M, Mittal A, Mehta PK. Microbial enzymes: Industrial progress in 21st century. Biotech. 2016; 6:174.

33. Tiwari SP, Srivastava R, Singh CS, Shukla K, Singh RK, Singh P, Singh R, Singh NL,Sharma R. Amylases: An overview with special reference to alpha amylase. Journal of Global Biosciences. 2015; 4(1):1886-1901.

34. Sundarram A, Murthy TPK. $\alpha$-Amylase Production and Applications: A Review Journal of Applied \& Environmental Microbiology. 2014; 2(4):166-175.

35. Garg G, Singh A, Kaur A, Singh R, Kaur J, Mahajan R. Microbial pectinases: an ecofriendly tool of nature for Industries. Biotech. 2016; 6(1):47-59.
36. Aguilar-Toalá JE, Santiago-López L, Peres CM, Peres C, Garcia HS, Vallejo-Cordoba B, González-Córdova AF, Hernández-Mendoza A. Assessment of multifunctional activity of bioactive peptides derived from fermented milk by specific Lactobacillus plantarum strains. Journal of Dairy Science. 2016; 100:65-75.

37. Agyei D, Ongkudon CM, Wei CY, Chan AS, Danquah MK. Bioprocess challenges to the isolation and purification of bioactive peptides. Food and Bioproducts Processing. 2016; 98:244-256.

38. Zhang Q, Han Y, Xiao H. Microbial $\alpha$-amylase: A biomolecular overview. Process Biochemistry. 2017; 53:88-101.

39. Hussain I, Siddique F, Mahmood MS, Ahmed SI. A review of the microbiological aspect of alpha-amylase production. Int J Agric Biol. 2013; 15:1029-34.

40. Suganthi R, Benazir JF, Santhi R, Ramesh Kumar V, Anjana Hari, Nitya Meenakshi, Nidhiya KA, Kavitha G, Lakshmi R. Amylase Production by Aspergillus Niger Under Solid State Fermentation Using Agroindustrial Waste. International Journal of Engineering Science and Technology. 2011; 3(2):1756-1763.

41. Patel A, Singhania R, Pandey A. Novel enzymatic processes applied to the food industry. Curr. Opin. Food Sci. 2016; 7:64-72.

42. Andualema B, Gessesse A. Microbial lipases and their industrial applications: review. Biotechnology.2012; 11:100-118.

43. Dalmaso GZL, Ferreira D, Vermelho AB. Marine extremophiles: a source of hydrolases for biotechnological applications. Mar. Drugs. 2015; 13:1925-1965.

44. Dionisi HM, Lozada M, Olivera NL. Bioprospection of marine microorganisms: biotechnological applications and methods. Rev. Argent. Microbiol. 2012; 44:49-60.

45. Ferrer M, Martínez-Martínez M, Bargiela R, Streit WR, Golyshina OV, Golyshin PN. Estimating the success of enzyme bioprospecting through metagenomics: current status and future trends. Microb. Biotechnol. 2016; 9:22-34.

46. Zhang C, Kim SK. Application of marine microbial enzymes in the food and pharmaceutical industries. Adv. Food Nutr. Res. 2012; 65:423-435.

47. Pallavi Pogaku P, Bhavani T, Manjusha, Saritha K. Lipases in Environmental Management. Int. J. Curr. Res. Aca. Rev. 2017; 5(4):106-109.

48. Mehta A, Saun NK, Gupta R. Purification and Characterization of Lipase from thermophilic Geobacillus sp, Current Biotechnology. 2016; 5 (1):81-89.

49. Muthumari GM, Thilagavathi S, Hariram N. Industrial Enzymes: Lipase Producing Microbes from Waste Volatile Substances. Int J Pharm Sci Res. 2016; 7(5):2201-08.

50. Sundarram A, Krishna Murthy TP. $\alpha$-Amylase production and applications: A Review. Journal of Applied \& Environmental Microbiology. 2014; 2(4):166-175.

\section{How to cite this article:}

Vittaladevaram V. Fermentative Production of Microbial Enzymes and their Applications: Present status and future prospects. J App Biol Biotech. 2017; 5 (04): 090-094. 